\title{
Edge Effect on the Litter Production of a Semi-Deciduous Seasonal Forest Fragment
}

\author{
Patrícia Anjos Bittencourt Barreto-Garcia ${ }^{1}$ (D), Monalisa Fagundes Oliveira ${ }^{1}$ (D), \\ Francisco Garcia R. B. Oliveira ${ }^{1}$ (D) Laís Ribeiro Lima Lacerda ${ }^{1}$ (C) \\ ${ }^{1}$ Universidade Estadual do Sudoeste da Bahia (UESB), Vitória da Conquista, BA, Brasil
}

\begin{abstract}
The edge effect makes forest communities more susceptible to changes and may cause changes in different ecosystem characteristics such as litter production. The objective of this work was to evaluate the edge effect on the contribution of litter and its temporal variation in a Semi-Deciduous Seasonal Forest fragment located in Vitória da Conquista, BA, Brazil. Four sampling ranges were delimited in the forest fragment: edge (0-10 m from the edge), transition 1 ( $40-50 \mathrm{~m}$ from the edge), transition 2 (80-90 $\mathrm{m}$ from the edge) and interior (400-410 $\mathrm{m}$ from the edge). The produced litter was collected monthly. The main litter components were leaves and branches in all sampling ranges. The contribution of the other fractions obeyed different orders at the edges (bark $>$ reproductive structures) and interior (reproductive structures $>$ bark). The edge effect did not influence the contribution of total litter and its temporal variation, only manifesting in the production of reproductive structures.
\end{abstract}

Keywords: leafing, deposition, forest fragmentation. 


\section{INTRODUCTION AND OBJECTIVES}

The intense use of natural resources has historically led to reducing areas of native vegetation and a consequent increase in the occurrence of isolated forest fragments devoid of ecological corridors. Among the Brazilian biomes, the Atlantic Forest is certainly one of the most affected. Most of its forest remnants are fragmented, especially dispersed in heavily cultivated, heavily disturbed, little-known and precariously protected landscapes (Silva et al., 2016).

In Bahia, the situation of the Atlantic Forest does not differ from that observed elsewhere in the country, occupying only $6 \%$ of its original area in the state's territory (Numa, 2015). One of the phytophysiognomies most affected by fragmentation within this biome is the Semi-Deciduous Seasonal Forest, being the predominant forest formation in Planalto da Conquista, BA. Its remnants are divided into fragments and under heavy pressure from expanding agriculture and urban centers. However, although this territory is constantly reducing, this forest formation is still little studied.

The damage caused by forest fragmentation appears to be extensive, virtually influencing the entire ecosystem and their communities (Laurance et al., 2000). The division of a large-scale population into two or more non-interconnected subpopulations promotes an increase in the proportion of margins, favoring the occurrence of abrupt edges, which are exposed to increased sunshine, wind and desiccation (Laurance et al., 2003).

Thus, the edge effect makes forest communities more susceptible to changes and may cause changes in microclimatic conditions up to hundreds of meters into the forest (Harper et al., 2005). This effect has been reproduced in different ways in vegetation, such as the change in composition and plant richness (Bernardi \& Budke, 2010; Ferreira et al., 2016) and in litter production and accumulation (Portela \& Santos, 2007; Santos et al., 2017; Vidal et al., 2007; Vogel et al., 2013).

Litter constitutes the main transfer path in the nutrient flow, playing an essential role in maintaining forest ecosystems, since it enables the return of nutrients and carbon from the vegetal biomass to the soil through decomposition (Godinho et al., 2014). According to Scoriza et al. (2012), the litter represents all organic material deposited on the soil, being both structures of plant and animal origin, which mainly includes leaves, flowers, branches, fruits and seeds. This organic layer, as well as the shoot and root of the vegetation, also provides protection to the soil and favors reestablishment of its physical, chemical and biological properties (Costa et al., 2007; Ikpe et al., 2003).

In addition to being influenced by the floristic composition and the forest successional stage, the deposited litter also suffers from several factors such as climate, soil fertility and the occurrence of anthropic interference (Vitousek \& Sanford, 1986). As a result, litter contribution is capable of responding to changes in the environment and can be used as an environmental indicator to monitor the conservation status of forest fragments.

In view of the above, the objective of this work was to evaluate the edge effect on litter contribution and its temporal variation in a Semi-Deciduous Seasonal Forest.

\section{MATERIALS AND METHODS}

The study was conducted in a Montana SemiDeciduous Seasonal Forest fragment, known regionally as "mata de cipó", located in the municipality of Vitória

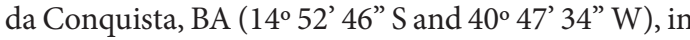
Planalto da Conquista, which has an average altitude of $915 \mathrm{~m}$. The vegetation is relatively low (height between $10 \mathrm{~m}$ and $15 \mathrm{~m}$ ), partially deciduous and surrounded by lianas, with a predominance of ecotypes from Parapiptadenia and Anadenanthera genera, usually associated to Cavanillesia, Tabebuia and Cedrela genera, among others (IBGE, 2012).

The fragment presents considerable intact area and average regeneration stage. Despite this, it is totally isolated from other forest patches by agricultural areas. A more detailed characterization of the fragment's condition in the landscape is presented in Table 1. For this, Trakemaker Pro software and Google Earth images from the year 2014 were used, which enabled obtaining the indices: total area (ha); nuclear area (ha) - $50 \mathrm{~m}$ borderless fragment area (Murcia, 1995); distance between the studied fragment and others greater than 50 ha (ISO) and proximity of forest fragments (PROX) - obtained by Equation 1:

$\operatorname{PROX}=\Sigma\left(\mathrm{A} / \mathrm{D}^{2}\right)$

A: area of the neighboring fragment $\left(\mathrm{m}^{2}\right)$; D: distance edge to edge between the main fragment and the neighboring fragment, admitting a maximum radius of $800 \mathrm{~m}$ from the edge (Vidal et al., 2007). 
Table 1. Spatial characterization of the fragment in the landscape.

\begin{tabular}{|c|c|c|c|c|}
\hline \multicolumn{2}{|c|}{ Area (ha) } & \multirow{2}{*}{$\begin{array}{c}\text { Elevation } \\
\text { (m) }\end{array}$} & \multirow{2}{*}{$\begin{array}{l}\text { ISO } \\
(\mathrm{m})\end{array}$} & \multirow{2}{*}{$\begin{array}{c}\text { PROX } \\
(\mathbf{m})\end{array}$} \\
\hline Total & Nuclear & & & \\
\hline 45.0 & 32.0 & 915 & 661.5 & 2.87 \\
\hline
\end{tabular}

ISO: isolation index; PROX: proximity index.

Four sampling ranges (strips) were delimited in the forest fragment to evaluate the edge effect: (1) edge positioned at the edge of the forest, $0-10 \mathrm{~m}$ from the edge; (2) transition 1 - allocated at 40-50 $\mathrm{m}$ from the edge, representing a transition zone close to the edge; (3) transition 2 - positioned at $80-90 \mathrm{~m}$ from the edge; and (4) interior - corresponding to the central part of the fragment, located in the middle of the total distance between the ends of the fragment, in the direction of strip demarcation (400-410 $\mathrm{m}$ from the edge).

The soil under the studied forest fragment has clay-sandy texture and belongs to the Dystrophic Yellow Latosol Class, presenting chemical characteristics according to Table 2 .

The climate of the region is tropical altitude (Cwb) according to the Koppen classification, with an average temperature of $25{ }^{\circ} \mathrm{C}$ and annual precipitation of $850 \mathrm{~mm}$. The mean values of temperature, relative humidity, precipitation and wind speed in the study period (December 2011 to November 2012) are shown in Table 3.

Table 2. Chemical characterization of the soil (depth $0-10 \mathrm{~cm}$ ) in four sampling ranges of the Semi-Deciduous Seasonal Forest fragment.

\begin{tabular}{|c|c|c|c|c|c|c|c|c|c|}
\hline Strip & pH & $\mathbf{P}$ & $\mathbf{K}^{+}$ & $\mathrm{Ca}^{2+}$ & $\mathrm{Mg}^{2+}$ & $\mathbf{H}^{+}+\mathbf{A l}^{3+}$ & BS & CEC & SOM \\
\hline & & $\mathrm{mg} \mathrm{dm}$ & & -- & $--\mathrm{cm}$ & $\mathrm{dm}^{-3}$ & 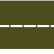 & & $\mathrm{g} \mathrm{dm}^{-}$ \\
\hline Edge & 5.6 & 2.7 & 0.16 & 2.2 & 1.0 & 3.3 & 3.4 & 6.7 & 36.7 \\
\hline Transition 1 & 5.1 & 1.0 & 0.13 & 3.0 & 1.2 & 4.1 & 4.3 & 8.5 & 54.3 \\
\hline Transition 2 & 5.0 & 1.0 & 0.11 & 3.1 & 1.1 & 4.0 & 4.3 & 8.4 & 51.3 \\
\hline Interior & 4.6 & 2.3 & 0.15 & 2.5 & 1.2 & 6.2 & 3.9 & 10.1 & 54.7 \\
\hline
\end{tabular}

Analyses performed according to Embrapa (2011): $\mathrm{pH}$ (water); $\mathrm{P}$ and K extractable by Mehlich ${ }^{-1}$; $\mathrm{Ca}$, Mg and Al exchangeable for KCl $1 \mathrm{~mol}$ $\mathrm{L}^{-1}$ and organic matter (SOM) by oxidation with $\mathrm{Na}_{2} \mathrm{Cr}_{2} \mathrm{O}_{7} 4 \mathrm{~N}$. CEC: cation-exchange capacity, BS: base sum. For each sampling range, three samples composed of 10 simple samples, collected in the $0-10 \mathrm{~cm}$ layer, by random walking.

Table 3. Mean monthly values of temperature, relative humidity, precipitation and wind speed from December 2011 to November 2012, in Vitória da Conquista, BA. Data provided by the Meteorological Station of Universidade Estadual do Sudoeste da Bahia.

\begin{tabular}{lcccc} 
& \multicolumn{4}{c}{ Climatic variables } \\
\cline { 2 - 5 } Month/year & T mean & RH & Ppt & Wind \\
\cline { 2 - 5 } & ${ }^{\circ} \mathbf{C}$ & $\%$ & mm & 4.4 \\
\hline $12 / 2011$ & 23.2 & 84.6 & 132.8 & 4.5 \\
$01 / 2012$ & 22.8 & 78.3 & 17.30 & 2.1 \\
\hline $02 / 2012$ & 22.5 & 74.7 & 29.30 & 2.0 \\
\hline $03 / 2012$ & 23.7 & 70.7 & 12.20 & 2.2 \\
\hline $04 / 2012$ & 23.6 & 68.6 & 1.7 & 2.0 \\
\hline $05 / 2012$ & 20.3 & 81.5 & 30.2 & 1.9 \\
\hline $06 / 2012$ & 20.6 & 79.1 & 22.20 & 2.2 \\
\hline $07 / 2012$ & 19.2 & 78.8 & 18.00 & 3.0 \\
\hline $08 / 2012$ & 18.4 & 79.6 & 55.30 & 2.6 \\
\hline $09 / 2012$ & 20.9 & 78.2 & 6.70 & 4.6 \\
\hline $10 / 2012$ & 22.0 & 77.5 & 48.40 & 1.4 \\
\hline $11 / 2012$ & 22.2 & 90.00 & 358.4 & \\
\hline
\end{tabular}

T mean: mean temperature; RH: relative air humidity; Ppt: rainfall; Wind: wind speed. 
In order to evaluate the litter production, five square collectors of $0.25 \mathrm{~m}^{2}(0.5 \times 0.5 \mathrm{~m})$ were installed in each sampling range, which were randomly distributed. The collectors had a nylon mesh bottom with a onemillimeter mesh and feet that kept them suspended $0.20 \mathrm{~m}$ from the ground, thus avoiding contact with the forest floor.

The litter deposited in the collectors was collected monthly from December 2011 to November 2012. The material collected each month was sorted and only separated into four fractions (leaves, branches, bark and reproductive structures), since there was no occurrence of non-identifiable waste, which would define a miscellaneous fraction. The fractions were dried in an oven $\left(60^{\circ} \mathrm{C}\right.$ for $\left.72 \mathrm{~h}\right)$ and weighed. The monthly and total yields of each of the sampling ranges in $\mathrm{kg} \mathrm{ha}^{-1}$ were estimated from the dry mass results, according to Equations 2 and 3:

$$
\begin{aligned}
& \mathrm{PS}_{\text {monha }}=\frac{\left(\mathrm{PS}_{\text {mon }} * 10.000\right)}{\mathrm{A}_{\mathrm{c}}} \\
& \mathrm{PS}_{\text {totalha }}=\sum \mathrm{PS}_{\text {monha }}
\end{aligned}
$$

$\mathrm{PS}_{\text {mon/ha }}$ : monthly litter production per hectare $\left(\mathrm{kg} \mathrm{ha}^{-1} \mathrm{month}^{-1}\right)$; PS : litter production in the month $\left(\mathrm{kg} \mathrm{mon}^{-1}\right)$; Ca: collector area $\left(\mathrm{m}^{2}\right) ; \mathrm{PS}_{\text {total/ha }}$ : total litter production $\left(\mathrm{kg} \mathrm{ha}^{-1}\right)$.

The litter production data for the fractions and total were submitted to normality analysis (Lilliefors test) and homogeneity of error variance (Cochran and Bartlett test). After verifying the non-normality and homogeneity of the data, the Kruskal-Wallis non-parametric test was adopted at 5\% significance for comparisons between sampling ranges.

Spearman correlations were established at 5\% significance between litter production and climatic variables (mean temperature, relative humidity, precipitation) in order to evaluate the influence of climatic factors on litter production during the study period. Pearson correlations were also established at $5 \%$ significance between litter production and soil chemical attributes. Analyses were performed using the SAEG v.9.1 program.

\section{RESULTS AND DISCUSSION}

The average annual litter production for the fragment as a whole was $4.3 \mathrm{Mg} \mathrm{ha}^{-1}$ (Table 4), a value close to that found in several studies in semi-deciduous seasonal forests in Brazil, such as by Bianchi et al. (2016) (4.7 $\left.\mathrm{Mg} \mathrm{ha}^{-1}\right)$, Werneck et al. (2001) (5.0 $\left.\mathrm{Mg} \mathrm{ha}^{-1}\right)$, Martins \& Rodrigues (1999) $\left(5.9 \mathrm{Mg} \mathrm{ha}^{-1}\right)$ and Pinto et al. (2008) $\left(6.3 \mathrm{Mg} \mathrm{ha}^{-1}\right)$. However, higher results were observed by other authors in studying this same forest typology, who obtained $11.7 \mathrm{Mg} \mathrm{ha}^{-1}$ (Pezzatto \& Wisniewski, 2006) and 11.9 $\mathrm{Mg} \mathrm{ha}^{-1}$ (Toscan et al., 2017).

The lower annual litter yield observed in this study may be related to the fact that the semi-deciduous seasonal forest studied was located in a transition zone between Caatinga and Atlantic Forest (Santos Neto et al., 2015), which implied a lower mass of plant residues deposited on the ground.

In the sampling ranges, the annual contributions were $4.0 \mathrm{Mg} \mathrm{ha}^{-1}$ (edge), 3.6 $\mathrm{Mg} \mathrm{ha}^{-1}$ (transition 1), 4.4 $\mathrm{Mg} \mathrm{ha}^{-1}$ (transition 2) and $5.1 \mathrm{Mg} \mathrm{ha}^{-1}$ (interior), with an increasing gradient in the edge-interior direction, although without significant variation. The monthly litter production also did not vary between the strips (Table 4), representing an average of $355.9 \mathrm{~kg} \mathrm{ha}^{-1}$ in the fragment. When studying forest fragments of the Atlantic Forest, Portela \& Santos (2007) also did not find significant differences in total litter production $\left(670.8 \mathrm{~kg} \mathrm{ha}^{-1}\right.$ month $\left.^{-1}\right)$ in relation to the interior $\left(691.7 \mathrm{~kg} \mathrm{ha}^{-1} \mathrm{month}^{-1}\right)$. On the other hand, in evaluating Secondary Atlantic Forest fragments, Vidal et al. (2007) found a lower contribution of litter on the edge and higher in the center of the fragment.

When comparing the average monthly yield of each of the fractions between the fragment strips, significant differences were only found for the deposition of reproductive structures (RS) (Table 4), which was lower in the edge, presented intermediate value in transition 1 , and was higher inside the fragment and in transition 2. This shows that the RS fraction was the most responsive litter component to the interferences of the edge effect, which extended up to $40 \mathrm{~m}$ to the interior of the fragment (transition 1).

The differences found in RS deposition should be related to the fact that forest fragmentation and the consequent loss of habitats affect fundamental stages of the plant life cycle such as pollination, seed dispersal, seedling recruitment and survival (Silva \& Tabarelli, 2000). According to Melo et al. (2006), fruit and seed production in the edge area is influenced by the greater exposure to abiotic factors such as temperature, 
precipitation and wind, which causes a reduction in the number of large seeds and the dispersion by vertebrates.

Lower amounts of litter at the edge were also verified by Vogel et al. (2013), who analyzed litter accumulation in a seasonal forest fragment in Rio Grande do Sul, and by Brasil et al. (2013), who observed a reduction in the biomass production of the edge area of Cerrado-Amazonian Forest, extending up to $35 \mathrm{~m}$ into the fragment interior.

Regarding the distribution of the litter-forming material, it was observed that the leaf fraction contributed the most to the total contribution regardless of the fragment strip, representing proportions between $75.1 \%$ in transition 2 and $81.7 \%$ at the edge of the fragment. Several studies in tropical forests have also found that leaves are the main litter component deposited on the soil, with contributions higher than 60 \% (Bianchi et al., 2016; Martins \& Rodrigues, 1999; Pinto et al., 2008; Santos Neto et al., 2015).

After leaves, the branches fraction was the second main component forming the litter in all the sampling strips, with an average contribution of $19.2 \%$. At the edge and transition 1 , the average participation of the other fractions followed the order: bark $(1.3 \%)>$ reproductive structures $(0.6 \%)$. In transition 2 and the interior, the distribution sequence was reproductive structures $(1.5 \%)>$ bark $(0.7 \%)$ (Table 4$)$. This differentiation in the distribution of the bark and RS fractions between the edge and the interior shows the possible influence of the edge effect on the deposition of these components, being in accordance with results previously discussed. The distribution pattern observed at the edge is similar to that found by Pezzatto \& Wisniewski (2006) in a semi-deciduous seasonal forest in western Paraná, while the pattern observed in the interior is similar to that found by Santos Neto et al. (2015), in semi-deciduous seasonal forest in southwestern Bahia.
When evaluating the variation of the total litter deposition throughout the year (December 2011 to November 2012) (Figure 1), it was observed that the edge presented the highest contribution in the months of April and June (average of $500.7 \mathrm{~kg} \mathrm{ha}^{-1}$ ). The interior deposition peak also occurred in April (786.00 $\left.\mathrm{kg} \mathrm{ha}^{-1}\right)$, while this occurred in the month of November in transition strips (transition $1=446.3 \mathrm{~kg} \mathrm{ha}^{-1}$ and transition $2=720.9 \mathrm{~kg} \mathrm{ha}^{-1}$ ) (Figure 1). April was the month with the lowest rainfall, while the month of November defined the beginning of the rainy season, with the highest precipitation index of the year. It is probable that the maximum production of the transitional strips in November was a consequence of the previous dry months, considering that the dry season in the study year extended from January to October, which may have implied a delay in the vegetation response to the hydric stress. Litter deposition coinciding with drier months of the year or with the end of the dry season constitute a typical seasonal pattern of semi-deciduous seasonal forests as a response of the vegetation to climatic variation (Dias \& Oliveira Filho, 1997). However, several researchers have reported higher litter production in the transition of dry season to early rainy season (Pinto et al., 2008; Werneck et al., 2001).

Although the maximum deposition coincided with the dry season (edge and interior) or the beginning of the rainy season (transition 1 and 2), only significant associations between litter production and climatic variables occurred at the edge and in the two transition strips (Table 5), with no correlation in the interior strip. This result suggests that in the three strips closer to the edge (meaning up to $90 \mathrm{~m}$ to the interior of the fragment) the climate interfered in the litter contribution with greater intensity. According to Murcia (1995), the edge suffers greater exposure to climatic factors due to being exposed to open environments, which can cause

Table 4. Average monthly and annual litter production in the forest fragment strips.

\begin{tabular}{|c|c|c|c|c|c|c|}
\hline \multirow{2}{*}{ Strip } & Leaves & Branches & Bark & RS & \multicolumn{2}{|c|}{ Total litter } \\
\hline & \multicolumn{4}{|c|}{$\mathrm{kg} \mathrm{ha}^{-1}$ month $^{-1}$} & $\mathrm{~kg} \mathrm{ha}^{-1}$ month $^{-1}$ & $\mathrm{~kg} \mathrm{ha}^{-1}$ year $^{-1}$ \\
\hline Edge & $273.85 \mathrm{a}$ & $56.11 \mathrm{a}$ & $4.49 \mathrm{a}$ & $0.89 \mathrm{c}$ & $335.33 \mathrm{a}$ & $4.024 .00 \mathrm{a}$ \\
\hline Transition 1 & $234.63 \mathrm{a}$ & $57.33 \mathrm{a}$ & $3.45 \mathrm{a}$ & $2.77 \mathrm{~b}$ & $298.18 \mathrm{a}$ & $3.578 .16 \mathrm{a}$ \\
\hline Transition 2 & $275.43 \mathrm{a}$ & $82.06 \mathrm{a}$ & $3.55 \mathrm{a}$ & $5.69 \mathrm{a}$ & $366.73 \mathrm{a}$ & $4.400 .80 \mathrm{a}$ \\
\hline Interior & $338.21 \mathrm{a}$ & $77.63 \mathrm{a}$ & $1.85 \mathrm{a}$ & $5.76 \mathrm{a}$ & $423.44 \mathrm{a}$ & $5.081 .28 \mathrm{a}$ \\
\hline
\end{tabular}

RS: reproductive structures. Means followed by the same letter in the column do not differ by the Kurskal-Wallis test at $5 \%$ significance. 


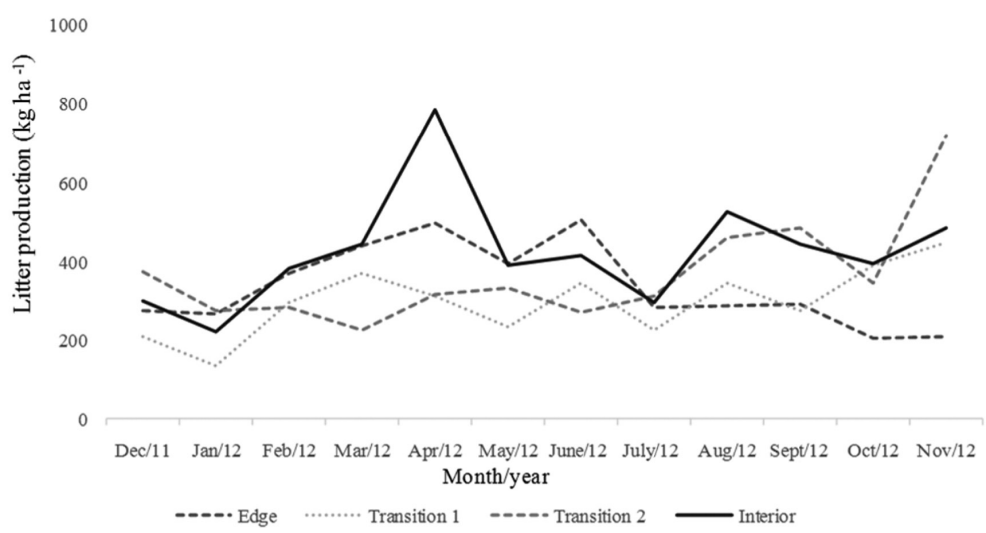

Figure 1. Monthly litter production in a period of 12 months (December 2011 to November 2012) in the sampling strips of the forest fragment.

severe modifications in its microclimatic conditions up to many meters into the forest. Therefore, a lower influence of climate on the fragment interior should be related to its better preservation condition and greater vegetation densification.

There was a positive correlation between the temperature and the contribution of branches at the edge, and a negative correlation between the precipitation and the total litter production and leaf fraction (Table 5). This latter association corroborates previously discussed results, indicating higher leaf deposition in the driest period. In transition 1, there was a negative association between relative humidity (RH) and leaf yield, while this same climatic variable correlated positively with branch production in transition 2 (Table 5). Martins \& Rodrigues (1999), Pezzatto \& Wisniewski (2006) and Pinto et al. (2008) verified a negative correlation between total litter production and relative humidity in semi-deciduous seasonal forest. However, studies on litter deposition generally tend to present diverse correlation patterns with climate. For example, when studying the seasonal forest in Rio Grande Sul, König et al. (2002) observed a significant association between temperature and leaves.

The temporal variation pattern in leaf and branch deposition in the sampling strips was similar to that of the total litter (Figure 2A and 2B), with maximum yields between mid and late dry season. This indicates that vegetation is responsive to water stress, using the fall of senescent plant material as a mechanism to reduce water loss through transpiration. This behavior is common in forests with a high proportion of deciduous species,
Table 5. Spearman non-parametric correlation coefficients between litter and climatic variables.

\begin{tabular}{|c|c|c|c|c|}
\hline \multirow{2}{*}{ Litter } & \multicolumn{4}{|c|}{ Climatic variables } \\
\hline & Temp & RH & Ppt & Wind \\
\hline & \multicolumn{4}{|c|}{ Edge } \\
\hline Leaves & $-0.01^{\mathrm{ns}}$ & $-0.48^{\mathrm{ns}}$ & $-0.59^{*}$ & $-0.45^{\mathrm{ns}}$ \\
\hline Branches & $0.78^{*}$ & $-0.10^{\mathrm{ns}}$ & $-0.07^{\mathrm{ns}}$ & $-0.09^{\text {ns }}$ \\
\hline Bark & $-0.46^{\mathrm{ns}}$ & $0.15^{\mathrm{ns}}$ & $0.01^{\mathrm{ns}}$ & $-0.07^{\mathrm{ns}}$ \\
\hline RS & $0.15^{\mathrm{ns}}$ & $0.34^{\mathrm{ns}}$ & $0.23^{\mathrm{ns}}$ & $0.12^{\mathrm{ns}}$ \\
\hline \multirow[t]{2}{*}{ Total } & $0.08^{\mathrm{ns}}$ & $-0.36^{\mathrm{ns}}$ & $-0.55^{*}$ & $-0.43^{\mathrm{ns}}$ \\
\hline & \multicolumn{4}{|c|}{ Transition 1} \\
\hline Leaves & $-0.02^{\mathrm{ns}}$ & $-0.57^{*}$ & $-0.18^{\mathrm{ns}}$ & $0.00^{\mathrm{ns}}$ \\
\hline Branches & $0.11^{\mathrm{ns}}$ & $0.32^{\mathrm{ns}}$ & $0.43^{\text {ns }}$ & $-0.19^{\text {ns }}$ \\
\hline Bark & $0.06^{\mathrm{ns}}$ & $-0.26^{\mathrm{ns}}$ & $-0.27^{\mathrm{ns}}$ & $-0.27^{\mathrm{ns}}$ \\
\hline RS & $-0.28^{\mathrm{ns}}$ & $0.18^{\mathrm{ns}}$ & $0.04^{\text {ns }}$ & $-0.00^{\mathrm{ns}}$ \\
\hline \multirow[t]{2}{*}{ Total } & $0.03^{\mathrm{ns}}$ & $-0.11^{\mathrm{ns}}$ & $0.22^{\mathrm{ns}}$ & $-0.41^{\mathrm{ns}}$ \\
\hline & \multicolumn{4}{|c|}{ Transition 2} \\
\hline Leaves & $-0.38^{\mathrm{ns}}$ & $0.09^{\mathrm{ns}}$ & $0.17^{\mathrm{ns}}$ & $-0.12^{\mathrm{ns}}$ \\
\hline Branches & $-0.34^{\mathrm{ns}}$ & $0.78^{*}$ & $0.46^{\mathrm{ns}}$ & $0.02^{\mathrm{ns}}$ \\
\hline Bark & $-0.30^{\mathrm{ns}}$ & $0.48^{\mathrm{ns}}$ & $0.12^{\text {ns }}$ & $-0.15^{\mathrm{ns}}$ \\
\hline RS & $0.462^{\mathrm{ns}}$ & $0.12^{\mathrm{ns}}$ & $0.25^{\mathrm{ns}}$ & $0.42^{\mathrm{ns}}$ \\
\hline \multirow[t]{2}{*}{ Total } & $-0.31^{\mathrm{ns}}$ & $0.50^{\mathrm{ns}}$ & $0.50^{\mathrm{ns}}$ & $0.18^{\mathrm{ns}}$ \\
\hline & \multicolumn{4}{|c|}{ Interior } \\
\hline Leaves & $-0.20^{\mathrm{ns}}$ & $0.03^{\mathrm{ns}}$ & $0.01^{\mathrm{ns}}$ & $-0.42^{\mathrm{ns}}$ \\
\hline Branches & $0.36^{\mathrm{ns}}$ & $-0.15^{\mathrm{ns}}$ & $0.25^{\mathrm{ns}}$ & $0.30^{\mathrm{ns}}$ \\
\hline Bark & $-0.17^{\mathrm{ns}}$ & $-0.02^{\mathrm{ns}}$ & $-0.11^{\mathrm{ns}}$ & $0.34^{\mathrm{ns}}$ \\
\hline RS & $0.19^{\text {ns }}$ & $0.33^{\text {ns }}$ & $0.13^{\text {ns }}$ & $0.36^{\mathrm{ns}}$ \\
\hline Total & $0.01 \mathrm{~ns}$ & $-0.14 n s$ & $-0.08 n s$ & $-0.30 \mathrm{~ns}$ \\
\hline
\end{tabular}

ns: not significant; ${ }^{*}$ : significant at $5 \%$ of significance, $n=48$; Temp: mean temperature; RH: relative air humidity; Ppt: rainfall; Wind: wind speed. 

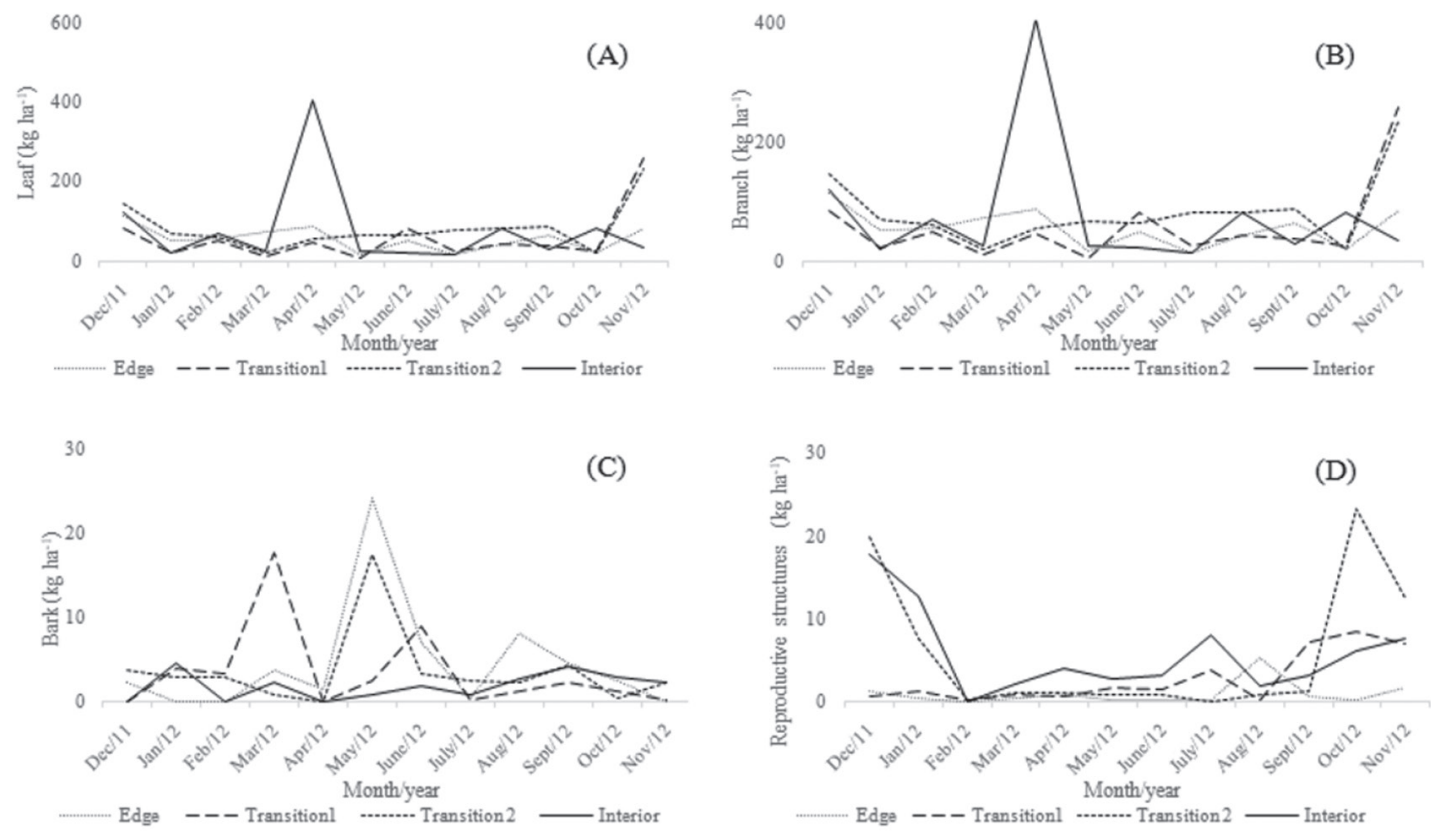

Figure 2. Monthly production of litter fractions over a period of 12 months (December 2011 to November 2012) in the sampling strips of the forest fragment: (A) leaves, (B) branches, (C) bark and (D) reproductive structures.

which intensify the abscission of their leaves in the cold season (König et al., 2002), and has been observed in several studies on litter contribution in semi-deciduous and deciduous seasonal forests (Pinto et al., 2008; Santos Neto et al., 2015; Toscan et al., 2017).

The temporal variation in the fall of bark and reproductive structures was quite irregular among the sampling strips (Figure 2), with production peaks occurring in different periods of the year. This may be reflecting phenological and floristic differences between the sampling ranges. Peak production occurred in the months of March (for transition 1), May (for the edge and transition 2) and January and September (for interior) (Figure 2C). On the other hand, RS deposition presented its maximum in August for the edge, and between September and December for the other strips (Figure 2D). The highest seed yields in semi-deciduous seasonal forests are generally observed at the end of the dry season (between August and September) and are usually related to fruit production in that period (Diniz \& Pagano, 1997; Toscan et al., 2017).

In general, the results of litter deposition verified in this study did not reflect differences indicating a high edge effect magnitude. Despite this, it was possible to observe that the chemical characteristics of the soil in the sampling ranges indicate the existence of a variation gradient in the edge-interior direction of the fragment (Table 2), especially in terms of $\mathrm{pH}$, cation-exchange capacity (CEC) and organic matter content. In this sense, significant correlations of the total litter supply with $\mathrm{pH}(p<0.05 ; \mathrm{r}=-0.69)$ and soil CEC ( $p<0.05 ; \mathrm{r}=-0.65)$ were observed, suggesting that soil fertility influenced the litter deposition pattern in the studied forest fragment. This is an indication of the importance of jointly evaluating different environmental indicators, such as litter and soil quality attributes, since it may enable better interpretation of the changes resulting from the edge effect, and consequently the conservation state of forest fragments.

\section{CONCLUSIONS}

The edge effect did not influence the contribution or seasonal pattern of the total litter deposition and most of its fractions. Only the production of reproductive structures was sensitive to the variations imposed by fragmentation, with effects up to a distance of $50 \mathrm{~m}$ from the edge towards the interior fragment. 


\section{SUBMISSION STATUS}

Received: 10 Oct., 2017

Accepted: 24 Nov., 2018

\section{CORRESPONDENCE TO}

\section{Patrícia Barreto-Garcia \\ Universidade do Sudoeste da Bahia (UESB), Estrada do Bem Querer, km 4, CEP 45031-300, Vitória da Conquista, BA, Brasil e-mail: patriciabarreto@uesb.edu.br}

\section{REFERENCES}

Bernardi S, Budke JC. Estrutura da sinúsia epifítica e efeito de borda em uma área de transição entre floresta estacional semidecídua e floresta ombrófila mista. Floresta 2010; 40(1): 81-92. 10.5380/rf.v40i1.17101

Bianchi MO, Scoriza RN, Correia MEF. Influência do clima na dinâmica de serrapilheira em uma floresta estacional semidecidual em Valença, RJ, Brasil. Revista Brasileira de Biociências 2016; 14(2): 97-101.

Brasil LS, Giehl NFS, Santos JO, Santos AO, Marimon BS, Marimon BH Jr. Efeito de borda sobre a camada de serapilheira em área de cerradão no leste de Mato Grosso. Biotemas 2013; 26(3): 37-47. 10.5007/2175-7925.2013v26n3p37

Costa CCA, Souza AM, Silva NF, Camacho RGV, Dantas IM. Produção de serapilheira na caatinga da Floresta Nacional do Açú-RN. Revista Brasileira de Biociências 2007; 5(Suppl. 1): 246-248.

Dias HCT, Oliveira Filho AT. Variação temporal e espacial da produção de serapilheira em uma área de floresta Estacional Semidecídua Montana em Lavras-MG. Revista Árvore 1997; 21(1): 11-26.

Diniz S, Pagano SN. Dinâmica de folhedo em floresta mesófila semidecídua no município de Araras, SP I: produção, decomposição e acúmulo. Revista do Instituto Florestal 1997; 9(1): 27-36.

Empresa Brasileira de Pesquisa Agropecuária - Embrapa. Manual de métodos de análise de solo. Rio de Janeiro: Embrapa Solos; 2011.

Ferreira TS, Marcon AK, Salami B, Rech CCC, Mendes AR, Carvalho AF et al. Composição florístico-estrutural ao longo de um gradiente de borda em fragmento de floresta ombrófila mista alto-montana em Santa Catarina. Ciência Florestal 2016; 26(1): 123-134. 10.5902/1980509821097

Godinho TO, Caldeira MVW, Rocha JHT, Caliman JP, Trazzi PA. Quantificação de biomassa e nutrientes na serapilheira acumulada em trecho de floresta estacional semidecidual submontana, ES. Cerne 2014; 20(1): 11-20. 10.1590/S0104-77602014000100002

Harper KA, MacDonald SE, Burton PJ, Esseen PA. Edge influence on forest structure and composition in fragmented landscapes. Conservation Biology 2005; 19(3): 768-782. 10.1111/j.1523-1739.2005.00045.x

Ikpe FN, Owoeye LG, Gichuru MP. Nutrient recycling potential of Tephrosia candida in cropping systems of southeastern Nigeria. Nutrient Cycling in Agroecosystems 2003; 67(2): 129-136. 10.1023/A:1025591719556

Instituto Brasileiro de Geografia e Estatística - IBGE. Manual técnico da vegetação brasileira. 2nd ed. Brasília: IBGE; 2012.

König FG, Schumacher MV, Brun EJ, Seling I. Avaliação da sazonalidade da produção de serapilheira uma floresta estacional decidual no município de Santa Maria - RS. Árvore 2002; 26(4): 429-335. 10.1590/S010067622002000400005

Laurance WF, Delamonica P, Laurance SG, Vasconcelos HL, Lovejoy TE. Rainforest fragmentation kills big trees. Nature 2000; 404(6780):836. 10.1038/35009032

Laurance WF, Merona JMR, Andrade A, Laurance SG, D’Angelo S, Lovejoy TE et al. Rain-forest fragmentation and the phenology of Amazonian tree communities. Journal of Tropical Ecology 2003; 19(3): 343-347. 10.1017/ S0266467403003389

Martins SV, Rodrigues RR. Produção de serapilheira em clareiras de uma floresta estacional semidecidual no município de Campinas, SP. Revista Brasileira de Botânica 1999; 22(3): 405-412, 1999.

Melo FPL, Dirzo R, Tabarelli M. Biased seed rain in forest edges: evidence from the Brazilian Atlantic forest. Biological Conservation 2006; 132(1): 50-60. 10.1016/j. biocon.2006.03.015

Murcia C. Edge effects in fragmented forests: implications for conservation. Trends in Ecology e Evolution 1995; 10(2): 58-62. 10.1016/S0169-5347(00)88977-6

Núcleo Mata Atlântica - Numa. A Mata Atlântica na Bahia. 2015 [cited 2017 July 15]. Available from: https:// bit.ly/2JN0bNI

Pezzatto AW, Wisniewski C. Produção de serapilheira em diferentes seres sucessionais da floresta estacional semidecidual no oeste do Paraná. Floresta 2006; 36(1): 111-120. 10.5380/rf.v36i1.5596

Pinto SIC, Martins SV, Barros NF, Herly C, Dias T. Produção de serapilheira em dois estádios sucessionais de floresta estacional semidecidual na reserva mata do paraíso, em Viçosa, MG. Revista Árvore 2008; 32(3): 545556. 10.1590/S0100-67622008000300015

Portela RCQ, Santos FAM. Produção e espessura da serapilheira na borda e interior de fragmentos florestais de Mata Atlântica de diferentes tamanhos. Revista 
Brasileira de Botânica 2007; 30(2): 271-280. 10.1590/ S0100-84042007000200011

Santos RS, Barreto-Garcia PAB, Scoriza RN. Fungos micorrízicos arbusculares e serapilheira como indicadores do efeito de borda em fragmento de floresta estacional. Ciência Florestal 2017; 28(1): 324-335. 10.5902/1980509831603

Santos Neto AP, Barreto PAB, Rodrigues EFG, Novaes $A B$, Paula A. Produção de serapilheira em floresta estacional semidecidual e em plantios de Pterogyne nitens Tul. E Eucalyptus urophylla S. T. Blake no sudoeste da Bahia. Ciência Florestal 2015; 25(3): 633643. 10.5902/1980509819614

Scoriza RN, Pereira MG, Pereira GHA, Machado DL, Silva EMR. Métodos para coleta e análise de serrapilheira aplicados à ciclagem de nutrientes. Série Técnica Floresta e Ambiente 2012; 2(2): 1-18.

Silva JMC, Pinto LP, Hirota M, Bedê L, Tabarelli M. Conservação da Mata Atlântica brasileira: um balanço dos últimos dez anos. In: Cabral DC, Bustamant EAG, organizadores. Metamorfoses florestais: culturas, ecologias e as transformações históricas da Mata Atlântica. Curitiba: Prismas; 2016. p. 434-460.

Silva JMS, Tabarelli M. The species impoverishment and the future flora of the Atlantic Forest of northeast Brazil. Nature 2000; 404: 72-74. 10.1038/35003563
Toscan MAG, Temponi LG, Guimarães ATB. Caracterização da produção de serapilheira e da chuva de sementes em uma reserva de floresta estacional semidecidual, Paraná. Ciência Florestal 2017; 27(2): 415427. 10.5902/1980509827725

Vidal MM, Pivello VR, Meirelles ST, Metzger JP. Produção de serapilheira em Floresta Atlântica Secundária numa paisagem fragmentada (Ibiúna, SP): importância da borda e tamanho dos fragmentos. Revista Brasileira de Botânica 2007; 30(3): 521-532. 10.1590/S010084042007000300016

Vitousek PM, Sanford RL Jr. Nutrient cycling in moist tropical forest. Annual Review of Ecology and Systematics 1986; 17: 137-167. 10.1146/annurev.es.17.110186.001033

Vogel HLM, Lorentz LH, Azevedo JVS, Rott LAG, Motta MSM. Efeito de borda no estoque de serapilheira e nutrientes em um fragmento de floresta nativa no Bioma Pampa-RS. Ecologia e Nutrição Florestal 2013; 1(1): 46-54. 10.13086/2316-980x.v01n01a05

Werneck MS, Pedralli G, Gieseke LF. Produção de serapilheira em três trechos de uma floresta semidecidual com diferentes graus de perturbação na Estação Ecológica de Tripuí, Ouro Preto, MG. Revista Brasileira de Botânica 2001; 24(2): 195-198. 10.1590/ S0100-84042001000200009 